\title{
Evaluation of Opuntia ficus indica $f$. inermis fruit juice hepatoprotective effect upon ethanol toxicity in rats
}

\author{
Hichem Alimi ${ }^{1,2}$, Najla Hfaeidh ${ }^{3}$, Sakhria Mbarki ${ }^{3}$, Zouhour Bouoni ${ }^{1}$, Mohsen Sakly² \\ and Khémais Ben Rouma ${ }^{2}$ \\ ${ }^{1}$ Research unit of Macromolecular Biochemistry and Genetic, Faculty of Sciences of Gafsa, 2112 Gafsa, Tunisia \\ ${ }^{2}$ Laboratory of Integrated Physiology, Faculty of Science of Bizerte, 7021 Jarzouna, Bizerte, Tunisia \\ ${ }^{3}$ Laboratory of Animal Ecophysiologie, Faculty of Science of Sfax, 3018 Sfax, Tunisia
}

\begin{abstract}
The aim of our present study is to investigate the effect of Opuntia ficus indicaf. inermis prickly pear juice (PPJ) against ethanol-induced liver injury in rats. Chronic ethanol administration $(3 \mathrm{~g} / \mathrm{kg}$ b.w.) during 90 days to Wistar rats, significantly $(p<0.01)$ increased the liver lipid and protein oxidation, reduced the glutathione content and the activities of liver antioxidant enzymes such as superoxide dismutase, catalase, glutathione peroxidase and conversely elevated the liver injury biochemical markers like aspartate aminotransferase, alanine aminotransferase, alkaline phosphatase, gamma glutamyl transferase, lactate dehydrogenase, cholesterol, triglycerides and caused a severe histopathologic injuries. Conversely pre-treatment of ethanol-fed rats with PPJ (20 and $40 \mathrm{ml} / \mathrm{kg}$ b.w., orally), interestingly reduced liver lipid and protein oxidation, histopathologic lesions and inhibited the alterations of antioxidant enzymes and the release of biochemical markers. The hepatoprotective effect of PPJ could be due to their capacity to end free radicals chain reactions or to enhance the endogenous antioxidants activities.
\end{abstract}

Key words: Opuntia - Ethanol — Liver injury

Abbreviations: ALP, alkaline phosphatase; ALT, alanine aminotransferase; AST, aspartate aminotransferase; CAT, catalase; GGT, gamma glutamyl transferase; GSH, reduced glutathione; GSH-Px, glutathionne peroxidase; $\mathrm{LDH}$, lactate dehydrogenase; MDA, malondialdehyde; PC, protein carbonyls; PPJ, Opuntia ficus indica f. inermis prickly pear juice; ROS, reactive oxygen species; SOD, superoxide dismutase.

\section{Introduction}

Alcoholic beverages which are widely consumed in the world contain mainly ethanol. Unlike methanol and propanol which are very toxic, ethanol can be converted into acetyl-CoA and, when kept at low concentration, metabolized as a nutriment. However, immoderate consumption of alcoholic beverages generates severe pathologies. Epidemiologic, experimental and clinical investigations have shown a consistent relationship between ethanol abuse and liver disease (Husain et al. 2001). One of the factors that play a central role in many pathways of ethanol-induced damage is oxidative stress (Abraham et al. 2002).

Correspondence to: Hichem Alimi, Unité de Biochimie Macromoléculaire et Génétique, Faculté des Sciences, 2112 Gafsa, Tunisia E-mail: alimihichem@yahoo.fr
Oxidative stress in the cells or tissues refers to the excessive generation of reactive oxygen species (ROS), leading to an increase of lipid peroxidation (Rajagopal et al. 2003), a lost of membrane integrity (Rakonczay et al. 2003), the depletion of the reduced glutathione (GSH) content, the attenuation of catalase (CAT), superoxide dismutase (SOD), and the glutathionne peroxidase (GSH-Px) activities (Yao et al. 2006). Moreover ethanol induced severe liver perturbations of cholesterol and triglycerides metabolism (Siler et al. 1999).

Damage to the liver after ethanol ingestion is a wellknown phenomenon, and the obvious sign of hepatic injury can be made by estimating the activities of serum aspartate aminotransferase (AST), alanine aminotransferase (ALT) and lactate dehydrogenase (LDH) known as hepatocyte cytoplasmic enzymes and gamma glutamyl transferase (GGT) and alkaline phosphatase (ALP) recognized as a membrane 
bound enzymes (Saravanan and Pugalendi 2006; Muthulingam et al. 2010).

For several years, a special attention was paid to the nutritional regimen and more particularly to natural products (fruits and vegetables) for their capacity to reduce toxicity of various xenobiotics and for their protective effects against oxidative stress and related diseases.

The cactus Opuntia ssp. is widely distributed in Latin America, South Africa and in the Mediterranean area (Butera et al. 2002). Opuntia ficus indica $f$. inermis species grows throughout Tunisia and their prickly pears are consumed as fresh fruits, juices or jams.

According to several studies, cactus fruits yield a great number of potentially active nutrients, such as ascorbic acid, vitamin E, carotenoids (Stintzing et al. 2001), large amount of glucose (35\%), fructose (29\%) (El Kossori et al. 1998), antioxidant compounds such as polyphenols, flavonoids, betaxanthin and betacyanin (Tesoriere et al. 2004), and appear as excellent additives for the development of healthy food.

Accordingly we hypothesized that prickly pears juice may prevent liver from the cytotoxic effects related to ethanol exposure.

In this study, we investigate whether the gastric instillation of Opuntia ficus indica $f$. inermis prickly pears juice (PPJ), could prevent ethanol-induced hepatic toxicity in male Wistar rats. Thus, the serum levels of AST, ALT, ALP, GGT, LDH, total cholesterol and triglycerides were determined. More so, hepatic levels of lipid peroxidation (MDA), protein carbonyl groups (PC) and antioxidant enzymes activities such as CAT, SOD and GSH-Px were also analyzed.

\section{Materials and Methods}

\section{Chemicals}

Ethanol was purchased from Carlo Erba (Reag.Ph. Eur.-Reag. USP), trichloroacetic acid (TCA), butylated hydroxytoluene (BHT), 2-thiobarbituric acid (TBA), 2,4-dinitrophenyl-hy-

Table1. Scheme of drugs treatment

\begin{tabular}{lcc}
\hline \multirow{2}{*}{ Groups } & \multicolumn{2}{c}{ Volumes of treatments (ml/kg b.w) } \\
\cline { 2 - 3 } & 9 a.m. & 1 p.m. \\
\hline Control & Water (10) & Water (10) \\
Ethanol & Water (10) & Ethanol (10) \\
PPJ2 + Ethanol & PPJ (20) & Ethanol (10) \\
PPJ4 + Ethanol & PPJ (40) & Ethanol (10) \\
PPJ4 & PPJ (40) & Water (10) \\
\hline
\end{tabular}

Distilled water was used as vehicle (Water). PPJ2 and PPJ4, prickly pear juice at dose 20 and $40 \mathrm{ml} / \mathrm{kg}$ b.w., respectively. drazine (DNPH), dithiobis-2-nitrobenzoic acid (DTNB), Folin-Ciocalteu reagent were purchased from Sigma chemical Co. (St. Louis, MO, USA). All other used chemicals and reagents were for analytic grade.

\section{Preparation of prickly pear juice (PPJ)}

Mature prickly pears of Opuntia ficus indica f. inermis species (purple-skinned) were collected in the municipal area of Gafsa (Tunisia). The unpeeled fruit was washed and grounded using a Musermax double bladed mill. The resulting juice was then filtered through a colander $(0.5 \mathrm{~mm}$ mesh size) and centrifuged at $3000 \times g$ for $10 \mathrm{~min}$ to discard hard fibres. The clarified juice was then collected and stored at $-21^{\circ} \mathrm{C}$ until use.

\section{Animals housing conditions}

Two months old male Wistar rats $(n=40)$, weighing about 120-140 g, purchased from Pasteur institute (Tunisia), were maintained for a two weeks adaptation period under the same conditions of temperature $\left(22 \pm 2^{\circ} \mathrm{C}\right)$, relative humidity $(70 \pm 4 \%)$, and a $12 \mathrm{~h} \mathrm{light/dark} \mathrm{cycle.} \mathrm{Animals} \mathrm{were} \mathrm{fed}$ with commercial pellets, given tap water ad libitum and cared according to the Tunisian code of practice for the Care and Use of Animals for Scientific Purposes.

\section{Treatments}

After the adaptation period, animals were divided into five experimental groups $(n=8)$ and treated for 90 days with two consecutive intra-gastric intubations of vehicle (distilled water), PPJ, ethanol (prepared at $30 \%$ in distilled water which was equivalent to $3 \mathrm{~g} / \mathrm{kg}$ b.w.) or both PPJ and ethanol according to the scheme described in Table 1.

\section{Serum collection and tissue homogenate preparation}

At the end of experimental period animals were anesthetized with diethyl ether and sacrificed by decapitation. The serum was collected by centrifugation of the whole blood at 1000 $\times g$ for 10 min at $4^{\circ} \mathrm{C}$ and stored at $-80^{\circ} \mathrm{C}$ until analysis. About $1 \mathrm{~g}$ of excised liver was cut into small pieces, homogenised into $2 \mathrm{ml}$ ice-cold lyses buffer ( $\mathrm{pH} 7.4$ ), sonicated twice and centrifuged for $20 \mathrm{~min}$ at $3000 \times g, 4^{\circ} \mathrm{C}$. The collected supernatants were stored at $-80^{\circ} \mathrm{C}$ until analysis.

\section{Biochemical analysis}

The activities of serum marker enzymes AST, ALT, ALP, GGT, LDH and the levels of triglycerides and cholesterol was assayed spectro-photometricelly using a BioMaghreb diagnostic kits. 
In liver homogenate the level of lipid peroxidation was measured as MDA content according to the method of Ohkawa et al. (1979). PC groups were evaluated according to the modified method of Burcham (2007) using urea instead of guanidine. Total GSH contents were measured by Ellman's reaction using 5,5-dithiobis 2- nitrobenzoic acid according to the method of Moron et al. (1979). SOD activity was estimated according to the method described by Misra and Fridovich (1972). CAT activity was determined by measuring hydrogen peroxide decomposition at 240 nm according to the method described by Aebi (1984). GSH-Px activity was assayed using the method described by Flohe and Gunzler (1984), by the subsequent oxidation of NADPH at $240 \mathrm{~nm}$.

\section{Protein determination}

Protein contents in tissue extracts were determined according to Lowry's method using bovine serum albumin as standard (Lowry et al. 1951).

\section{Liver histopathological studies}

Liver tissues were cut into about 5 -cm-thick slices and fixed with $10 \%$ phosphate-buffered formalin ( $\mathrm{pH} 7.4)$. The tissue slices were dehydrated through ascending grades of alcohol, and embedded in paraffin. Tissue sections of 5-8 $\mu \mathrm{m}$ were made using microtome, and stained with hematoxylin-eosin solutions (H\&E). Tissue preparations were observed and micro-photographed under a light $\mathrm{BH}_{2}$ Olympus microscope.

\section{Statistical analysis}

All the values have been reported as means \pm standard deviation of triplicate samples and were analyzed statistically by one way ANOVA and different group means were compared by Duncan's multiple range tests; $p<0.05$ was considered significant in all cases. The software SPSS 12.0 was used for analysis of data.

\section{Results}

Effect of ethanol and PPJ on liver MDA, PC and GSH contents

As shown in Fig. 1, a significant $(p<0.01)$ increase in hepatic MDA and PC was occurred by $82.6 \%$ and $84.5 \%$, respectively, in ethanol-treated rats, whereas pre-treatment with PPJ at low (PPJ2 = $20 \mathrm{ml} / \mathrm{kg}$ b.w.) and high (PPJ4 $=40 \mathrm{ml} / \mathrm{kg}$ b.w.) doses decreased hepatic MDA content by $29.92 \%(p<0.05)$ and $40.87 \%(p<0.01)$ and reduced
PC content by $39.58 \%(p<0.05)$ and $43.75 \%(p<0.01)$, respectively. As also showed in Fig. 1, hepatic GSH content of chronically ethanol-treated rats were significantly

$\mathbf{A}$

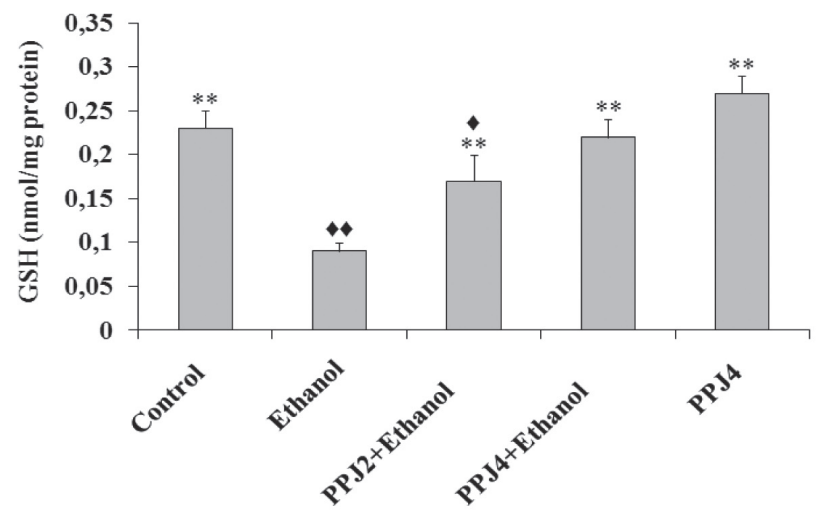

B

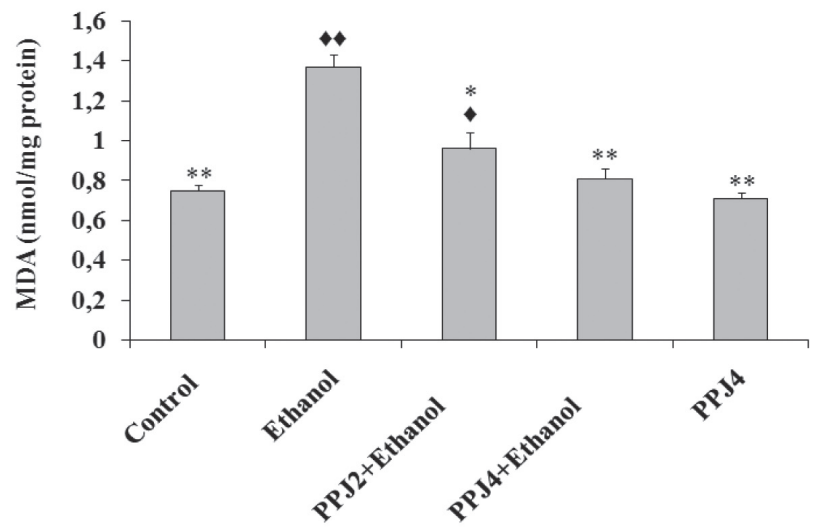

C

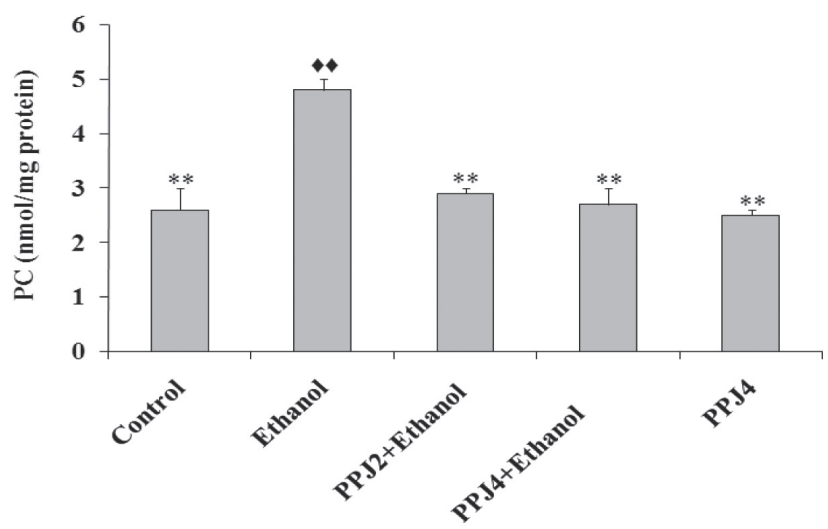

Figure 1. Effect of chronic ethanol ingestion ( $\mathrm{EtOH}=3 \mathrm{~g} / \mathrm{kg} \mathrm{b.w.}$, for 90 days), and low (PPJ2 $=20 \mathrm{ml} / \mathrm{kg}$ b.w.) or high (PPJ4 $=40 \mathrm{ml} / \mathrm{kg}$ b.w.) doses of PPJ on the levels of reduced glutathione (GSH; $\mathbf{A})$, malondialdehyde (MDA; B) and protein carbonyls $(\mathrm{PC} ; \mathbf{C})$ in rats liver. Values are expressed as means $\pm \operatorname{SD}(n=8) .{ }^{*} p<0.05,{ }^{* *} p<0.01$ versus ethanol group; ${ }^{\star} p<0.05,{ }^{\star} p<0.01$ versus control group. 
Table 2. Effects of ethanol and PPJ on the activities of hepatic markers enzymes

\begin{tabular}{lccccc}
\hline \multirow{2}{*}{ Groups } & \multicolumn{5}{c}{ Enzyme concentration (IU/l) } \\
\cline { 2 - 6 } & AST & ALT & PAL & LDH & GGT \\
\hline Control & $114.5 \pm 4.3^{\mathrm{a}}$ & $46.1 \pm 4.5^{\mathrm{a}}$ & $68.3 \pm 6.1^{\mathrm{a}}$ & $582.4 \pm 31.9^{\mathrm{a}}$ & $2.08 \pm 0.14^{\mathrm{a}}$ \\
Ethanol & $264.9 \pm 7.6^{\mathrm{bb}}$ & $93.2 \pm 5.3^{\mathrm{bb}}$ & $220.8 \pm 6.2^{\mathrm{bb}}$ & $1072.8 \pm 51.7^{\mathrm{bb}}$ & $6.32 \pm 0.29^{\mathrm{bb}}$ \\
PPJ2 + Ethanol & $118.6 \pm 8.1^{\mathrm{ab}}$ & $52.7 \pm 7.1^{\mathrm{a}}$ & $76.9 \pm 8.1^{\mathrm{a}}$ & $742.6 \pm 37.9^{\mathrm{a}}$ & $3.89 \pm 0.12^{\mathrm{a}}$ \\
PPJ4 + Ethanol & $123.9 \pm 8.5^{\mathrm{a}}$ & $47.8 \pm 3.8^{\mathrm{a}}$ & $70.1 \pm 10.1^{\mathrm{a}}$ & $584.3 \pm 41.8^{\mathrm{a}}$ & $2.24 \pm 0.12^{\mathrm{a}}$ \\
PPJ4 & $109.1 \pm 8.8^{\mathrm{a}}$ & $45.2 \pm 3.1^{\mathrm{a}}$ & $66.7 \pm 11.2^{\mathrm{a}}$ & $581.9 \pm 14.3^{\mathrm{a}}$ & $1.96 \pm 0.13^{\mathrm{a}}$ \\
\hline
\end{tabular}

Values are expressed as means $\pm \mathrm{SD}$, for eight rats in each group. ${ }^{\mathrm{a}} p<0.01$ when compared with ethanol group; ${ }^{\mathrm{b}} p<0.05,{ }^{\mathrm{bb}} p<0.01$ when compared with control group. AST, aspartate aminotransferase; ALT, alanine aminotransferase; ALP, alkaline phosphatase; LDH, lactate dehydrogenase; GGT, gamma glutamyl transferase; PPJ2 and PPJ4, prickly pear juice at dose 20 and $40 \mathrm{ml} / \mathrm{kg}$ b.w., respectively.

decreased by $60.86 \%(p<0.01)$ in comparison with the corresponding finding of normal rats. As compared with ethanol-treated rats, PPJ supplement at PPJ2 and PPJ4 doses increased hepatic GSH level by $47.05 \%(p<0.05)$ and $59.09 \%(p<0.01)$, respectively. Fig. 1 also showed that PPJ given alone to intact rats slightly reduced normal MDA and PC levels and slightly induced hepatic GSH synthesis when compared with control rats.

\section{Effect of ethanol and PPJ on serum markers of liver damage}

As it is obvious in Table 2, chronic ethanol administration significantly $(p<0.01)$ increased the activities of hepatic damage indicators AST, ALT, GGT, PAL and LDH in comparison with control rats. Pre-treatment of ethanol-fed with PPJ significantly $(p<0.01)$ reversed as dose-dependant manner the serum AST, ALT, GGT, PAL and LDH activities towards normal. There was no significant change in mean activity of serum hepatic markers enzymes in intact rats only treated by PPJ.

Table 3. Effects of ethanol and PPJ on the activities of hepatic antioxidant enzymes

\begin{tabular}{lccl}
\hline Groups & SOD $^{1}$ & CAT $^{2}$ & GSH-Px $^{3}$ \\
\hline Control & $121.17 \pm 5.3^{\mathrm{a}}$ & $23.1 \pm 2.5^{\mathrm{a}}$ & $2.8 \pm 0.6^{\mathrm{a}}$ \\
EtOH & $96.52 \pm 6.8^{\mathrm{bb}}$ & $9.6 \pm 3.1^{\mathrm{bb}}$ & $0.9 \pm 0.4^{\mathrm{bb}}$ \\
PPJ2 + Ethanol & $116.31 \pm 8.1^{\mathrm{ab}}$ & $15.2 \pm 2.3^{\mathrm{a}}$ & $2.2 \pm 0.8^{\mathrm{a}}$ \\
PPJ4 Ethanol & $118.92 \pm 5.2^{\mathrm{a}}$ & $21.6 \pm 5.7^{\mathrm{a}}$ & $2.7 \pm 0.7^{\mathrm{a}}$ \\
PPJ & $128.14 \pm 3.3^{\mathrm{a}}$ & $25.8 \pm 4.2^{\mathrm{a}}$ & $3.1 \pm 0.4^{\mathrm{a}}$ \\
\hline
\end{tabular}

Values are expressed as means $\pm \mathrm{SD}$, for eight rats in each group. ${ }^{\mathrm{a}} p<0.01$ when compared with ethanol group; ${ }^{\mathrm{b}} p<0.05,{ }^{\mathrm{bb}} p<0.01$ when compared with control group. ${ }^{1}$ Units/mg protein (one units of SOD activity is the amount of enzyme required to give $50 \%$ inhibition of epinephrine auto-oxidation); ${ }^{2} \mu \mathrm{mol}$ of $\mathrm{H}_{2} \mathrm{O}_{2}$ consumed $/ \mathrm{min} / \mathrm{mg}$ protein; ${ }^{3} \mathrm{nmol}$ of GSH oxidized/min $/ \mathrm{mg}$ protein. SOD, superoxide dismutase; CAT, catalase; GSH-Px, glutathionne peroxidase.

\section{Effect of ethanol and PPJ on liver antioxidants enzymes activities}

Table 3 represents the activities of SOD, CAT and GSH-Px in liver. Chronic ethanol administration was found to cause a significant decrease $(p<0.01)$ in the activities of antioxidant enzymes when compared with control group. However, PPJ supplement at low and high doses significantly $(p<0.01)$ increased SOD, CAT and GSH-Px activities, in dose-dependent manner, to reach normal values. The administration of PPJ4 alone for intact rats slightly induced SOD, CAT and GXH-Px activities when compared with control group.

\section{Effect of ethanol and PPJ on liver cholesterol and triglyceride levels}

As shown in Table 4, the chronic ethanol administration for control rats significantly increased the serum total cholesterol and triglycerides levels when compared with control rats $(p<0.01)$, while it returned to near normal levels when PPJ was pre-administered as dose-dependant manner. Table 4 also showed slightly reduced levels of serum total cholesterol and triglycerides in intact rats given PPJ4 as compared with control rats.

Table 4. Effect of PPJ on the serum triglycerides and cholesterol levels

\begin{tabular}{lcc}
\hline Groups & $\begin{array}{c}\text { Total cholesterol } \\
(\mathrm{mmol} / \mathrm{l})\end{array}$ & $\begin{array}{c}\text { Triglycerides } \\
(\mathrm{mmol} / \mathrm{l})\end{array}$ \\
\hline Control & $2.71 \pm 0.16^{\mathrm{a}}$ & $1.34 \pm 0.19^{\mathrm{a}}$ \\
Ethanol & $3.52 \pm 0.18^{\mathrm{bb}}$ & $2.34 \pm 0.14^{\mathrm{bb}}$ \\
PPJ2 + Ethanol & $2.89 \pm 0.41^{\mathrm{a}}$ & $1.61 \pm 0.28^{\mathrm{ab}}$ \\
PPJ4 + Ethanol & $2.73 \pm 0.13^{\mathrm{a}}$ & $1.33 \pm 0.13^{\mathrm{a}}$ \\
PPJ4 & $2.64 \pm 0.38^{\mathrm{a}}$ & $1.29 \pm 0.43^{\mathrm{a}}$ \\
\hline
\end{tabular}

Values are expressed as means \pm SD, for eight rats in each group. ${ }^{\mathrm{a}} p<0.01$ when compared with ethanol group; ${ }^{\mathrm{b}} p<0.05,{ }^{\mathrm{bb}} p<0.01$ when compared with control group. 


\section{Results of histological studies}

Histological examination of section taken from control rats showed the normal structure of liver tissue composing of polyhedral hepatocytes arranged in parenchyma (Fig. 2A). Chronic ethanol intake had an obvious damaging effect on liver tissue with the appearance of large and small fatty vacuoles rounded with large number of activated Kupffer cells (Fig. 2B). Pre-administration of PPJ to ethanol-fed rats showed marked improvement in liver tissue structure in spite of the presence of acidophilic hepatic cells, fatty vacuoles are nearly absent (Fig. 2C). The chronic administration of PPJ4 to intact rats did not cause any toxic effect in liver tissue which appeared near normal (Fig. 2D).

\section{Discussion}

This study was undertaken to determine whether a dietary regimen enriched by PPJ, could attenuate some of ethanol toxic effects on liver functions. Oxidative stress plays a capital role in the development of alcoholic liver diseases (Wu and Cederbaum 2003). The removal or neutralization of the noxious ethanol metabolites remained a primordial steps in the prevention of alcohol-related liver diseases (Ozaras et al. 2003; Kasdallah-Grissa et al. 2007).

In our study, ethanol-induced hepatotoxicity is evidenced by 1) significant increase of liver-related injury biomarkers in serum such as LDH, ALT, AST, GGT and ALP, 2) impairment of liver antioxidants such as GSH, SOD, CAT, and GSH-Px, 3) alteration of blood parameters linked to liver function such as cholesterol and triglycerides, 4) histological changes, including hepatocytes steatosis and activation of Kupffer cells. Our results are in agreements with similar observations reported by Jurczuk and co-workers (2004).

Liver is the main organ in charge of metabolizing ethanol via three different enzymes: alcohol dehydrogenase, cytochrome P450 (CYP2E1), and CAT (Lieber 1993). Ethanol metabolism led to the formation of cytotoxic acetaldehyde, which in turn was oxidized to acetate giving rise to ROS
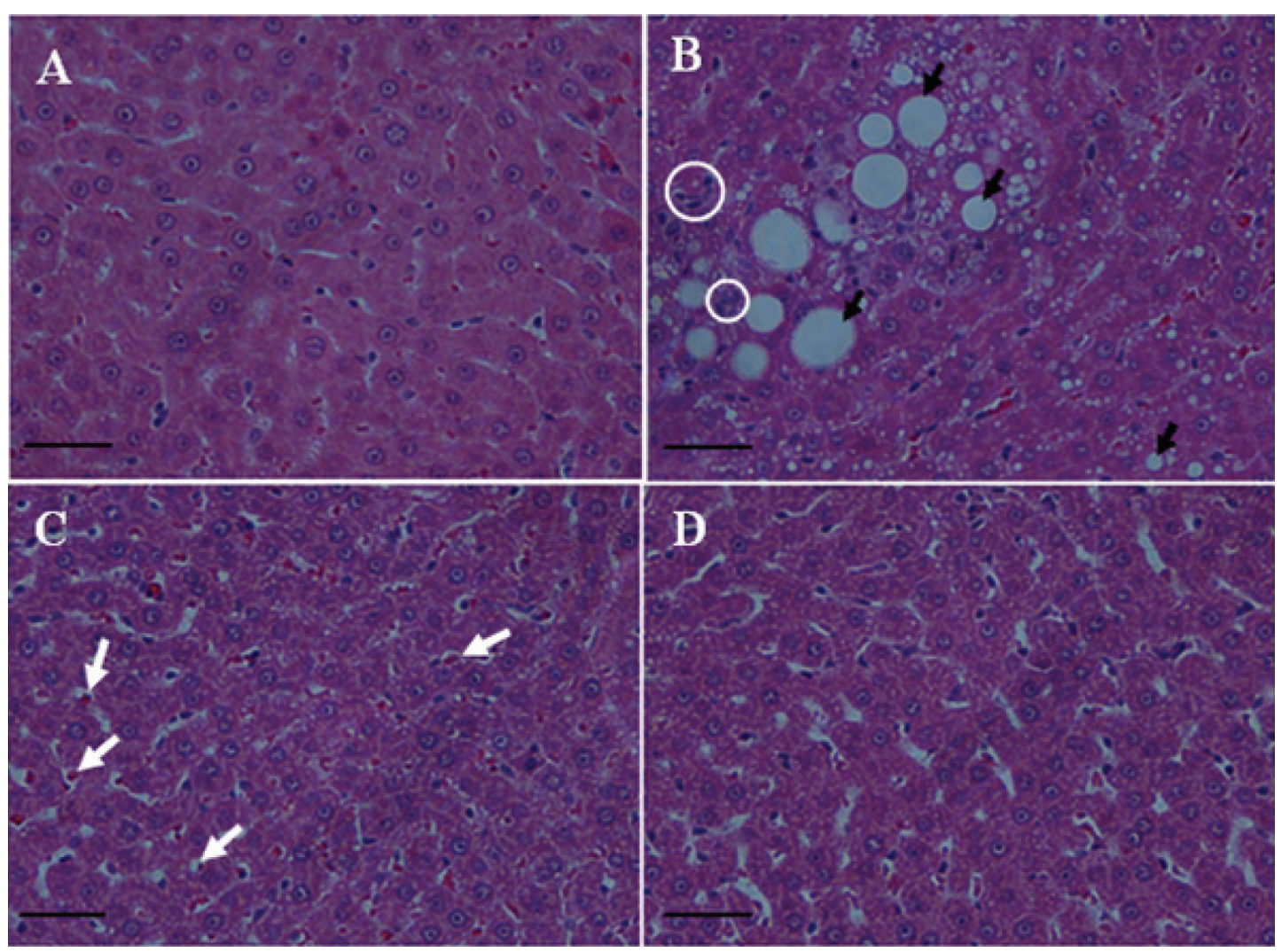

Figure 2. Light micrographs of hematoxylin-eosin (H\&E) stained liver (magnification $\times 40)$. A. Control rat liver showing normal hepatic parenchyma. B. Liver of rat treated with ethanol (3 g/kg b.w.), showing large fatty globules (black arrow) rounded with activated Kupffer cells (white circle). C. Liver of rat treated with ethanol (3 g/kg b.w.) + PPJ4 (40 ml $/ \mathrm{kg}$ b.w.) showing few number of acidophilic hepatic cells (white arrow) and a near normal appearance parenchyma without fatty vacuoles. D. Intact rat liver treated with PPJ4 (40 ml/kg b.w.), showing normal hepatic parenchyma. (Bars $=10 \mu \mathrm{m}$ ). 
(Fridovich 1989). ROS released from ethanol metabolism such as superoxide $\left(\mathrm{O} 2^{\bullet-}\right)$, hydroxyl $\left(\mathrm{HO}^{\bullet}\right)$, and alkoxyl $\left(\mathrm{RO}^{\circ}\right)$ radicals have a high potential to initiate lipid and protein oxidation (Nordmann et al. 1992). In agreement with previous studies, our results showed that chronic ethanol ingestion significantly increased liver tissue MDA and PC contents (Rajagopal et al. 2003). The lipid peroxidation started in ethanol-fed rats hepatocytes, leads to the lost of their membrane integrity evidenced by the leakage to the blood stream, of the membrane-bounded ALP, GGT and cytoplasmic AST, ALT and LDH enzymes, our results are in agreement with those reported by Pari and Suresh (2008).

In normal conditions hepatocytes possess a powerful antioxidant defense system, including enzymatic and nonenzymatic antioxidants such as SOD, CAT, GSH-Px and GSH (Jurczuk et al. 2004). However, under certain circumstances, chronic ethanol intake and antioxidant mechanisms fail can bring on oxidative stress (Parola and Robino 2001). The impairment of liver SOD, CAT, GSH-Px activities and GSH content has been reported in alcoholics and experimental animals (Ozaras et al. 2003). In consistent with these reports, our results also showed that chronic ethanol administration to untreated rats, decreased the liver GSH, SOD, CAT and GSH-Px levels. Such decreases can result from ROS depletion of the above antioxidants or to the suppression of the de novo protein synthesis (Husain et al. 2001; Yao et al. 2006).

It has been demonstrated that the impairment of the liver antioxidant status, the over production of ROS and acetaldehyde associated to ethanol intake inhibit the tricarboxylic acid cycle activity and fatty acid oxidation, leading to the increase of serum cholesterol and triglycerides content (Siler et al. 1999; Pari and Suresh 2008). In consistent with these reports our results also showed an evidence increase of serum triglycerides and cholesterol contents in alcoholic rats.

Pre-treatment of ethanol-fed rats with both PPJ 2 and PPJ4 significantly reversed hepatic lipid and protein oxidation as evidenced by the decrease of MDA and PC contents to near control levels. We have previously demonstrated that PPJ appears as a good candidate in the prevention of ethanolinduced lipid and protein oxidation in rat's erythrocytes (Alimi et al. 2012 b). In the present study we showed that PPJ diminished the ethanol-induced hepatic tissue injury as monitored by normal liver architecture when compared with alcoholic rats. Consistent with the improved morphology, treatment with PPJ was associated with a corresponding reduction in levels of serum cholesterol, triglycerides, AST, ALT, ALP, GGT, and LDH indicating a protective role of PPJ against ethanol toxicity in liver. Further more liver GSH content and activities of antioxidant enzymes, namely, SOD, CAT and GSH-Px were visibly ameliorated when PPJ was supplemented to ethanol-fed rat's diet.

A wide range of natural antioxidant compounds can protect the liver from damage via a variety of mechanisms.
In our previous study we have showed that PPJ was rich in polyphenols, flavonoids, ascorbic acid, carotenoids, and betalains. We have also demonstrated that PPJ supplement increased plasma scavenging activity of control and ethanolfed rats and prevented ethanol-induced impairment of erythrocyte osmotic stability and morphologic aspect (Alimi et al. 2012a). The PPJ active principles may acts by scavenging free radicals and ROS that causes the oxidative process in liver cells. The restoration of liver antioxidant status when PPJ was supplemented to alcoholic rat's diet may be attributed, in part, to the antioxidant sparing action of the polyphenolic compounds. In addition, administration of high PPJ dose to untreated rats slightly enhanced production of GSH, SOD, CAT and GSH-Px. Hence, hepatic protective effect of PPJ could be attributed in part to its safeguard and/or inductive effects on GSH, SOD, CAT and GSH-Px synthesis. Our results are in agreements with those of Myhrstad et al. (2002) and Moskaug et al. (2005) which reported that polyphenols was able to induce GSH biosynthesis via the up-regulation of $\gamma$-glutamylcysteine synthetase expression.

The HPLC analysis of phenolic acids extracted from PPJ, revealed the presence of gallic, protocatechic, 4-hydroxybenzoic, vanillic and syrengic acids (Alimi et al. 2012a). This kind of phenols was able to liberate a hydrogen proton from their hydroxyl groups which could scavenge free radicals and prevent hepatocytes from oxidative damage. In addition PPJ ascorbic acid, carotenoids and betalains contents are also known for their scavenging and reducing activities and could contribute to the protective effect of PPJ (Butera et al. 2002; Ganaraja et al. 2008). It has been showed that the main nutraceutical benefit of prickly pears and their juice has been attributed to the flavonoids contents (Kuti 2004). I our previous study the HPLC analysis of flavonoids extracted from PPJ revealed the presence of quercetin, luteolin, kaempferol and isorhamnetin (Alimi et al. 2012b). It was also demonstrated that flavonoids can be incorporated in cell plasma membranes, which becomes more ordered and therefore enhances their stability (Chaudhuri et al. 2007). The localization of flavonoids in the plasma membranes could strictly hinder the diffusion of free radicals, and thereby decreases resulting damage (Dobrzynska et al. 2005). Such flavonoids proprieties could explain the increase of hepatocyte membrane integrity evidenced by the decrease of MDA and PC contents, the restoration of the histological morphology, and the reduction of liver pathology markers in alcoholic rats. Ruther than scavenging and stabilizing capacities, it has been demonstrated that flavonoids may also inhibit the CYP 2E1 activity and/or decrease its content, thereby contributing to inhibit and/or to decrease ethanol metabolism, hence the occurrence of oxidative stress (Orellana et al. 2002).

In conclusion, this report is the first study examining the effect of PPJ on ethanol-inducing liver injury. The active components of PPJ could act synergistically in preventing 
ethanol toxicity, by scavenging free radicals and ROS, by stabilizing hepatocyte membrane integrity and restoring antioxidant enzymes levels. Hence, our study suggests that PPJ consumption may provide a useful approach for decreasing alcohol-induced liver damage.

Acknowledgements. This research was funded by the Tunisian Ministry of Higher Education and Scientific Research through Integrated Physiology Laboratory, Faculty of Science of Bizerte and the Research Unit of Macromolecular Biochemistry and Genetics, Faculty of Sciences of Gafsa.

\section{References}

Abraham P., Wilfred G., Ramakrishna B. (2002): Oxidative damage to the hepatocellular proteins after chronic ethanol intake in the rat. Clin. Chem. Acta 25, 117-125 http://dx.doi.org/10.1016/S0009-8981(02)00279-6

Aebi H. (1984): Catalase in vitro. Methods Enzymol. (Bergneyer H.U.) 105, 121-126

Alimi H., Hfaeidh N., Bouoni Z., Sakly M., Ben Rhouma K. (2012a): Protective effect of Opuntia ficus indica f. inermis prickly pear juice upon ethanol-induced damages in rat erythrocytes. Alcohol. 46, 235-243 http://dx.doi.org/10.1016/j.alcohol.2011.09.024

Alimi H., Hfaeidh N., Bouoni Z., Sakly M., Ben Rhouma K. (2012b): Ameliorative effect of Opuntia ficus indica juice on ethanolinduced oxidative stress in rat erythrocytes. Exp. Toxicol. Pathol. (in press).

http://dx.doi.org/10.1016/j.etp.2011.12.003

Burcham P.C. (2007): Modified protein carbonyl assay detects oxidised membrane proteins: A newtool for assessing drug- and chemically-induced oxidative cell injury. J. Pharmacol. Toxicol. Meth. 56, 18-22 http://dx.doi.org/10.1016/j.vascn.2006.02.015

Butera D., Tesoriere L., Di Gaudio F., Bongiorno A., Allegra M., Pintaudi A. M., Kohen R., Livrea M. A. (2002): Antioxidant activities of Sicilian prickly pear (Opuntia ficus indica) fruit extracts and reducing properties of its betalains: betanin and indicaxanthin. J. Agric. Food. Chem. 50, 6895-6901 http://dx.doi.org/10.1021/jf025696p

Chaudhuri S., Banerjee A., Basu K., Sengupta B., Sengupta P. K. (2007): Interaction of flavonoids with red blood cell membrane lipids and proteins: antioxidant and antihemolytic effects. Int. J. Biol. Macromol. 41, 42-48 http://dx.doi.org/10.1016/j.ijbiomac.2006.12.003

Dobrzynska I., Szachowicz-Petelska B., Ostrowska J., Skrzydlewska E., Figaszewski Z. (2005): Protective effect of green tea on erythrocyte membrane of different age rats intoxicated with ethanol. Chem. Biol. Interact. 156, 41-53 http://dx.doi.org/10.1016/j.cbi.2005.07.002

El Kossori R. L., Villaume C., El Boustani E., Sauvaire Y., Mejean L. (1998): Composition of pulp, skin and seeds of prickly pears fruit (Opuntia ficus indica sp.). Plant. Food. Hum. Nutr. 52, 263-267

http://dx.doi.org/10.1023/A:1008000232406
Flohé L., Günzler W. A. (1984): Assays of glutathione peroxidase. Methods Enzymol. 105, 114-121 http://dx.doi.org/10.1016/S0076-6879(84)05015-1

Fridovich I. (1989): Oxygen radicals from acetaldehyde. Free Radic. Biol. Med. 7, 557-558 http://dx.doi.org/10.1016/0891-5849(89)90032-4

Ganaraja B., Crystal D. D., Vijayalakshmi B. M., Nayanatara A. K., Ramesh B. M., Ramaswamy C. (2008): Use of vitamine C on effect of ethanol induced lipid peroxidation in various tissues, sperm count \& morphology in the Wistar rats. J. Chine.Clinic. Med. 3, 627-632

Husain K., Skott B. R., Reddy S. K., Somani S. M. (2001): Chronic ethanol and nicotine interaction on rat tissue antioxidant defense system. Alcohol 25, 89-97 http://dx.doi.org/10.1016/S0741-8329(01)00176-8

Jurczuk M., Brzóska M. M., Moniuszko-Jakoniuk J., Gałażyn-Sidorczuk M., Kulikowska-Karpinska E. (2004): Antioxidant enzymes activity and lipid peroxidation in liver and kidney of rats exposed to cadmium and ethanol. Food Chem. Toxicol. 42, 429-438 http://dx.doi.org/10.1016/j.fct.2003.10.005

Kasdallah-Grissa A., Mornagui B., Aouani E., Hammami M., El May M., Gharbi N., Kamoun A., El-Fazaâ S. (2007): Resveratrol, a red wine polyphenol, attenuates ethanol-induced oxidative stress in rat liver. Life Sci. 80, 1033-1039 http://dx.doi.org/10.1016/j.lfs.2006.11.044

Kuti J. O. (2004): Antioxidant compounds from four Opuntia cactus pear fruit varieties. Food. Chem. 85, 527-533 http://dx.doi.org/10.1016/S0308-8146(03)00184-5

Lieber C. S. (1993): Biochemical factors in alcoholic liver disease. Semin. Liver. Dis. 13, 136-153 http://dx.doi.org/10.1055/s-2007-1007345

Lowry O. H., Rosenbrough N. J., Randall R. (1951): Protein measurement with the folin phenol reagent. J. Biol. Chem. 193, 265-275

Misra H. P., Fridovich I. (1972): The role of superoxide anion in the autooxidation of epinephrine and a simple assay for superoxide dismutase. J. Biol. Chem. 247, 3170-3175

Moron M. A., De Pierre J. W., Mannervick B. (1979): Levels of glutathione, glutathione reductase and glutathione-S-transferase activities in rat liver. Biochim. Biophys. Acta 582, 67-78 http://dx.doi.org/10.1016/0304-4165(79)90289-7

Moskaug J. Ø., Carlsen H., Myhrstad M. C. W., Blomhoff R. (2005): Polyphenols and glutathione synthesis regulation. Am. J. Clin. Nutr. 81, 277-283

Muthulingam M., Mohandoss P., Indra N., Sethupathy S. (2010): Antihepatotoxic efficacy of Indigofera tinctoria (Linn.) on paracetamol induced liver damage in rats. Int. J. Pharm. Biomed. Res. 1, 13-18

Myhrstad M. C. W., Carlsen H., Nordström O., Blomhoff R., Moskaug J. Ø. (2002): Flavonoids increase the intracellular glutathione level by transactivation of the $\gamma$-glutamylcysteine synthetase catalytical subunit promoter. Free Radic. Biol. Med. 32, 386-393 http://dx.doi.org/10.1016/S0891-5849(01)00812-7

Nordmann R., Ribiere C., Rouach H. (1992): Implication of free radical mechanisms in ethanol induced cellular injury. Free Radic. Biol. Med. 12, 219-232

http://dx.doi.org/10.1016/0891-5849(92)90030-K 
Ohkawa H., Ohishi N., Yagi K. (1979): Assay for lipid peroxides in animal tissues by thiobarbituric acid reaction. Anal. Biochem. 95, 351-358

http://dx.doi.org/10.1016/0003-2697(79)90738-3

Orellana M., Varela N., Guajardo V., Araya J., Rodrigo R. (2002): Modulation of rat liver cytochrome $\mathrm{P} 450$ activity by prolonged red wine consumption. Comp. Biochem. Physiol. C 131, 161-166

Ozaras R., Tahan V., Aydin S., Uzun H., Kaya S., Santurk H. (2003): $\mathrm{N}$-acetylcysteine attenuates alcohol-induced oxidative stress in the rat. World J. Gastroenterol. 9, 125-128

Pari L., Suresh A. (2008): Effect of grape (Vitis vinifera L.) leaf extract on alcohol induced oxidative stress in rats. Food Chem. Toxicol. 46, 1627-1634

http://dx.doi.org/10.1016/j.fct.2008.01.003

Parola M., Robino G. (2001): Oxidative stress related molecules and liver fibrosis. J. Hepatol. 35, 297-306

http://dx.doi.org/10.1016/S0168-8278(01)00142-8

Rajagopal S. K., Manickam P., Periyasamy V., Namasivayam, N. (2003): Activity of Cassia auriculata leaf extract in rats with alcoholic liver injury. J. Nutr. Biochem. 314, 452-458

http://dx.doi.org/10.1016/S0955-2863(03)00053-6

Rakonczay J. Z., Boros I., Jarmay K., Hegyi P., Lonovics J., Takacs T. (2003): Ethanol administration generates oxidative stress in the pancreas and liver, but fails to induce heat-shock proteins in rats. J. Gastroenterol. Hepatol. 7, 858-867

http://dx.doi.org/10.1046/j.1440-1746.2003.03076.x
Saravanan R., Pugalendi V. (2006): Impact of ursolic acid on chronic ethanol-induced oxidative stress in the rat heart. Pharmacol. Rep. 58, 41-47

Siler S. Q., Neese R. A., Hellerstein M. K. (1999): De novo lipogenesis lipid kinetics and whole-body lipid balances in humans after acute alcohol consumption. A. J. Clinical. Nutr. 70, 928-936

Stintzing F. C., Schieber A., Carle R. (2001): Phytochemical and nutritional significance of cactus pear. Eur. Food. Res. Technol. 212, 396-407

http://dx.doi.org/10.1007/s002170000219

Tesoriere L., Butera D., Pintaudi A. M., Allegra M., Livrea M. A. (2004): Supplementation with cactus pear (Opuntia ficusindica) fruits decreases oxidative stress in healthy humans. A comparative study with vitamin C. Am. J. Clin. Nutr. 80, 391-395

Wu D., Cederbaum A. I. (2003): Alcohol, oxidative stress, and free radical damage. Alcohol Res. Health 27, 277-284

Yao P., Li K., Jin Y., Song F., Zhou S., Sun X., Nussler A. K., Liu L. (2006): Oxidative damage after chronic ethanol intake in rat tissues: Prophylaxis of Ginkgo biloba extract. Food. Chem. 99, 305-314

http://dx.doi.org/10.1016/j.foodchem.2005.07.047

Received: January 5, 2012

Final version accepted: February 21, 2012 